"Stimulation of effective ecological and economic interactions in the process of business environment creation"

\begin{tabular}{|c|c|}
\hline AUTHORS & Alexander Ishchenko \\
\hline ARTICLE INFO & $\begin{array}{l}\text { Alexander Ishchenko (2017). Stimulation of effective ecological and economic } \\
\text { interactions in the process of business environment creation. Environmental } \\
\text { Economics, } 8(2), 57-66 \text {. doi:10.21511/ee.08(2).2017.06 }\end{array}$ \\
\hline DOI & http://dx.doi.org/10.21511/ee.08(2).2017.06 \\
\hline RELEASED ON & Wednesday, 14 June 2017 \\
\hline RECEIVED ON & Tuesday, 07 March 2017 \\
\hline ACCEPTED ON & Friday, 05 May 2017 \\
\hline LICENSE & $\begin{array}{l}(c) \text { EY-No } \\
\text { This work is licensed under a Creative Commons Attribution-NonCommercial } 4.0 \\
\text { International License }\end{array}$ \\
\hline JOURNAL & "Environmental Economics" \\
\hline ISSN PRINT & $1998-6041$ \\
\hline ISSN ONLINE & 1998-605X \\
\hline PUBLISHER & LLC "Consulting Publishing Company "Business Perspectives" \\
\hline FOUNDER & LLC "Consulting Publishing Company "Business Perspectives" \\
\hline
\end{tabular}

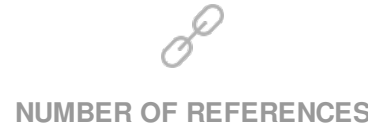

21

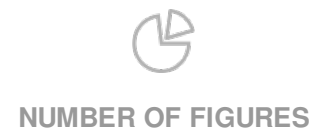

0
NUMBER OF TABLES

2

(C) The author(s) 2023. This publication is an open access article. 
Alexander Ishchenko (Ukraine)

\title{
Stimulation of effective ecological and economic interactions in the process of business environment creation
}

\begin{abstract}
The article substantiates the necessity of introducing a new national framework document that would outline strategic directions for long-term development of Ukraine and facilitate the integration of sustainable development into the national plans, strategies and programs. It provides recommendations concerning the projection of business environment taking into account environmental and economic constraints and green technologies in Ukraine, as well as the use of economic and mathematical modeling. It offers the introduction of ecological and economic projects to enhance control and responsibility for the implementation of the planned measures on all levels, constant examination of the current legislation regarding its compliance with the principles of sustainable development; active use of public examination and independent audit; ensuring continuous dialogue between representatives of business and society.
\end{abstract}

Keywords: ecological and economic interactions, "green" economy, sustainable development, projection of business environment.

JEL Classification: Q01, Q28.

Received on: $7^{\text {th }}$ of March, 2017.

Accepted on: $5^{\text {th }}$ of May, 2017.

\section{Introduction}

Economic growth, which is associated with a significant increase in the scale of consumption, increases the burden on the environment, which often leads to negative consequences that may become irreversible. Unfortunately, Ukraine has all signs of environmental crisis complicated by a prolonged economic crisis. That is why the problem of the low levels of "ecologization of production" not only poses a threat to the environment, but also casts doubt on the possibility of economic growth in the future.

Therefore, it seems necessary to stimulate environmental and economic interactions, creation of business environment that should take into account ecological and economic limits and use the advantages of green technologies.

On the international level, an important trend is the concept of sustainable development aimed at creating a new global economic ethics and environmentally sound development. For Ukraine, the priority area is the implementation of the recognized mechanisms of influence on ecological and economic cooperation and development of national programs containing the elements of stimulation of green technologies to ensure environmental and economic balance and sustainable development.

(C) Alexander Ishchenko, 2017.

Alexander Ishchenko, Doctor of Economics, Professor, Managing Partner of the Consulting Company SMM, Kyiv, Ukraine.

This is an Open Access article, distributed under the terms of the Creative Commons Attribution-NonCommercial 4.0 International license, which permits re-use, distribution, and reproduction, provided the materials aren't used for commercial purposes and the original work is properly cited.
The study's goal is to determine the nature of ecological and economic interactions and to carry out the analysis of processes that involve the projection of business environment based on ecological and economic interactions and standards of the green economy.

\section{Presentation of the main material}

Economic and ecological systems are relatively independent and develop according to their own laws, but in the process of their interactions, there arise specific relations that reflect the impact of natural elements and the laws of nature on the sphere of material production. There is also the need to regulate the impact of economic entities on environmental processes in the conditions of increasing industrial and economic burden on the environment.

Under ecological and economic interactions we understand the relationships that occur between economic entities in the process of nature management in the field of rational use of natural resources, their protection and restoration, utilization of waste and secondary raw materials, the greening of production in general. Good governance in nature management and environmental protection provides such environmental and economic interactions that enhance the motivation to reduce the negative impact on the ecological system.

It should be added that the current business environment is increasingly influenced by the management strategies focused on ecologization of production, thereby making it competitive on the national and international markets (A. Sutarmin, S.N. Darmawan, Azizah and D.P. Jatmiko, 2017). 
The issues of stimulation of effective environmental and economic interactions in Ukraine are closely intertwined with the existing mechanism of financing of environmental protection measures, the principles of which are defined by the legislation on environmental protection. In choosing the methods to stimulate environmental and economic interactions by the authorities, the preference is given to environmental regulation, limitation, licensing, expertise and control that ensure the compliance with the relevant standards and state regulations without providing economic preferences, which does not encourage economic entities to exercise a conscious and quality environmental activity. Considering the current environmental situation in Ukraine, it could be argued that regulatory mechanisms are insufficiently adapted to the demands of the market environment and do not fully correspond to the essence of the ongoing reforms (The Law of Ukraine "On Environmental Protection" of June 25, 1991 No. 41). For example, the role of the main source of funding for environmental activities is performed by the tax on air emissions of certain pollutants by the stationary sources of pollution, the rates of which are given in article 243 of the Tax Code of Ukraine (2010). Special funds of local budgets receive $80 \%$ of their revenues from this tax and they can only be used for financial support of environmental protection measures (Law of Ukraine "On Amendments to the Budget Code of Ukraine concerning the targeted use of environmental tax" of December 24, 2015 No. 918-VIII). Maximum permitted quantities of emissions are regulated by the norms of maximum allowable pollutant emissions from stationary sources (The Decree of the Ministry of Environmental Protection of Ukraine "On approval of maximum allowable pollutant emissions from stationary sources" of June 27, 2006 No. 309). As a result, there is an objective interest of state authorities in continuously high levels of pollutant emissions as a source of financial provision, which contradicts the idea of reducing the negative impact on the environment.

It is assumed that the achievement of efficient ecological and economic interactions and the projection of business environment taking into account environmental and economic constraints should be ensured by the state using a system of rewards and incentives, which, by law, include:

- provision of tax incentives for businesses and citizens in case of realization of measures aimed at rationally using the natural resources and environmental protection;

- provision on preferential terms of short- and longterm loans for the implementation of measures to ensure a sustainable use of natural resources and environmental protection;
- tax exemption for environmental protection funds;

- the transfer of environmental protection funds on a contractual basis to business entities and citizens to carry out measures aimed at guaranteeing the reduction of emissions and discharges of pollutants and reduction of the harmful physical, chemical and biological impact on the environment, the development of environmentally friendly technologies and industries;

- provision of opportunities to obtain natural resources against pledge.

According to the plan laid down by the legislation, the list of incentives would provide a quick "ecologization of enterprises", but, in practice, it turned out that there were no real mechanisms for their implementation and, accordingly, their impact on the environment was negligible. An outstanding characteristic of this condition is the fact that the first national "ecological" credit was obtained only in September 2016 (Official portal of executive power bodies of Ukraine), though the possibility of obtaining preferential loans for environmental projects was envisaged by the legislation since 1991.

Under these circumstances, to encourage and streamline environmental and economic interactions in Ukraine, it is particularly important to follow the course of achieving "sustainable development". In 1992, at the UN Millennium Summit in Rio de Janeiro, sustainable development was recognized as a global priority of humanity, which means a model of economic growth in which the use of resources is aimed at meeting human needs while preserving the environment with the expectation that these needs must be met not only for the present, but also for the future generations. Realization of the strategy of sustainable development involves a combination of economic efficiency, social stability and environmental safety (Report of the United Nations conference on environment and development, 3-14 June 1992).

In Ukraine, the ways of achieving sustainable development are regulated by the Sustainable Development Strategy "Ukraine - 2020" (hereinafter Strategy 2020), but the fundamental principle of sustainable development, namely the need to address environmental issues as a fundamental condition for achieving sustainable development, is practically not applied by the Strategy 2020. Specifically, there are virtually no details on the regulation of environmental and economic interactions in the implementation of the planned activities. Regarding environmental issues the document specified only the need to implement the "Program for environment preservation" as one of 
62 programs and reforms planned by the Strategy, but such a program on the national level has not yet been developed (Decree of the President of Ukraine "On Sustainable Development Strategy" Ukraine - 2020" of January 12, 2015 No. 5/2015). As part of the Strategy, 2020 the programs of environment preservation are developed and implemented only on the local level by individual administrative and territorial units (Sumy region, the town of Fastov, etc.) ("On approval of the Program of environment protection in the town of Fastov in 2016-2020" and "On the program of environmental protection of the Sumy region in 2016-2018").

This situation leads to the introduction of a new national framework document that would outline strategic directions for long-term development of Ukraine and facilitate the integration of sustainable development into the national plans, strategies and programs. Sufficiently complying with these requirements is a draft of the Sustainable Development Strategy of Ukraine till 2030 (hereinafter - Strategy 2030) developed with the support of the United Nations Development Program in Ukraine. Unlike the aforementioned current Strategy 2020, the draft of Strategy 2030 gives considerable attention to the regulation of environmental and economic interactions. One of the strategic objectives is to ensure the transition to the models of sustainable consumption and production, sustainable management of natural resources and improved approaches of responding to climate change, the realization of which requires: considerable (up to $40 \%$ ) reduction in resource intensity of GDP; comprehensive implementation of the systems of regulation of consumption of water, heating and energy; carrying out "green" procurements by the state; implementation of measures to improve energy efficiency and conservation; reduction in the formation of industrial wastes by $20 \%$ and optimization of their treatment by increasing the amount of waste that is recycled, incinerated or disposed of by $50 \%$; elimination of unauthorized dumps; reduction of losses in the food production and marketing chain by $20 \%$; reorientation of subsidies on the production and use of fossil fuels to support energy efficiency programs.

The values of the key indicators characterizing ecological and economic interactions and the values they need to reach within the framework of the Strategy 2030 are shown in Table 1.

Table 1. Estimates of indicators characterizing ecological and economic interactions within the Strategy 2030

\begin{tabular}{|c|c|c|c|c|}
\hline \multirow{2}{*}{ Scope } & \multirow{2}{*}{ Actual values as of 2015} & \multicolumn{3}{|c|}{ Values to be achieved in: } \\
\hline & & 2020 & 2025 & 2030 \\
\hline $\begin{array}{l}\text { The amount of generated waste, per unit of GDP, } \\
\mathrm{kg} / 1000 \text { US dollars }\end{array}$ & 1004 & 950 & 880 & 800 \\
\hline The share of recycled, incinerated and disposed of waste, \% & 30 & 40 & 50 & 70 \\
\hline $\begin{array}{l}\text { Recycling of waste stockpiled in areas of waste disposal, of the volume of } \\
2015, \%\end{array}$ & 0 & 5 & 15 & 25 \\
\hline Agricultural land area occupied by organic production, thousand hectares & 410.6 & 500 & 1500 & 3000 \\
\hline Resource intensity of GDP, compared to $2015, \%$ & 100 & 90 & 80 & 60 \\
\hline Energy intensity of GDP, $\mathrm{kg}$ of oil equivalent per 1 US dollar of GDP & 0.313 & 0.27 & 0.23 & 0.20 \\
\hline $\begin{array}{l}\text { The share of energy produced from renewable sources in the general final } \\
\text { energy consumption, \% }\end{array}$ & 6.7 & 11 & 14.2 & 17.1 \\
\hline
\end{tabular}

It should be noted that the proposed approach meets the objectives of the optimal regulation of environmental and economic interactions during the implementation of the new economic model based on the principles of sustainable (balanced) development, on the proven positive experience of planning by the UN, has clearly defined practical objectives and definitely needs legitimization at the state level.

Peculiarities of the "green economy" most fully correspond to the purposes and objectives of organization of optimum environmental and economic interactions as the main mechanism for transition to sustainable development. The United Nations Environment Program (UNEP) has developed a working definition of a green economy as one that results in improved human well-being and social equity, while significantly reducing environmental risks and ecological scarcities. Practically speaking, a green economy is one whose growth in income and employment is driven by public and private investments that reduce carbon emissions and pollution, enhance energy and resource efficiency, and prevent the loss of biodiversity and ecosystem services. These investments need to be catalyzed and supported by targeted public expenditure, policy reforms and regulation changes.

Implementation of the standards of the "green" economy is particularly important for Ukraine, because the country has environmental situation, which is close to catastrophic - energy 
dependence of Ukraine on the imports of fossil fuels is about $60 \%$, the process of land degradation is widespread, soil erosion covers $57 \%$ of the territory considering the fact that Ukraine has the world's largest black soil areas (official site of The State Service of Ukraine for Geodesy, Cartography and Cadastre (State Geo Cadastre)). The area of eroded land increases each year by more than 80 thousand hectares. Economic losses from erosion are already more than 10 billion US dollars per year. The wear of agricultural equipment in Ukraine is $40.7 \%$. Over the past ten years the number of agricultural equipment decreased by two times (The National Institute for Strategic Studies). Only in 2015, emissions into the atmosphere were 162071.9 thousand tons of carbon dioxide and 4521 thousand tons of pollutants (105.5 $\mathrm{kg}$ per person); there were created 312267.6 thousand tons of waste, of which only 92463.7 thousand tons were recycled; there were 875 million $\mathrm{m} 3$ of contaminated wastewaters dumped into surface waters (Official website of the State Statistics of Ukraine).

Transition to the standards of the "green" economy can provide a comprehensive solution of the above-mentioned problems by stimulating new business models that are based on environmentally friendly and commercially attractive foundations of profitable economic activities and thereby creating opportunities for designing effective business environment taking into account the existing environmental and economic constraints.

Modern processes of implementation of the "green" economy in Ukraine are associated with a number of administrative and institutional problems. The legal and regulatory framework for the development and implementation of programs and projects aimed at achieving a transition to the standards of the green economy and complex consideration of environmental and economic issues is the Basic Principles (Strategy) of the State Environmental Policy of Ukraine till 2020 approved by the law. Detailed measures relating to the implementation of the declared environmental policy are currently missing, because the draft of the National Action Plan on Environmental Protection for 2016-2020 has not been approved (the draft of the National Action Plan for Environmental Protection for 2016-2020 and the Law of Ukraine "On the foundations (strategy) of state environmental policy of Ukraine till 2020" of 21 December 2010 No. 2818-VI).
Analysis of the implementation of the Strategy of the National Environmental Policy of Ukraine till 2020 in the period from 2011 to 2015 and the National Action Plan on Environmental Protection for 2011-2015 demonstrates the ineffectiveness of realization of strategic objectives regulating ecological and economic interactions and low efficiency of the implemented ones, which were stipulated by the strategic goal No. 6 of the Strategy, measures to ensure an environmentally sustainable nature management.

The effectiveness of implementation of only one of these strategic objectives ("Increased use of renewable and alternative energy sources by $25 \%$ by 2015 and by $55 \%$ by 2020 from the basic level") is estimated in the range from 30 to $60 \%$. The following strategic objectives associated with implementation of regulation of ecological and economic interactions are fulfilled by no more than $30 \%$ :

- development of a national system of inventories of natural resources, state statistical reporting on the use of natural resources and environmental pollution;

- technical upgrading of production through the introduction of innovative projects, energyefficient and resource-saving technologies, lowwaste, waste-free and environmentally friendly manufacturing processes by 2020;

- introduction by 2015 of a system of economic and administrative mechanisms to encourage producers to sustainable and renewable use of natural resources and environmental protection, wide introduction of new cleaner technologies, innovations in environmental management;

- improvement of energy efficiency by 25 percent till 2015 and by 50 percent till 2020 compared to the base year by implementing resource conservation of energy in industries that consume energy and energy carriers;

- increase by 7 percent till 2020 in the share of land used for organic agriculture;

- creation by 2015 of environmentally and economically reasonable system of payments for the use of natural resources and taxes on pollution of the natural environment to stimulate business entities to carry out sustainable environmental management).

The strategic objective of reforming by 2015 the current system of environmental protection funds in order to enhance centralization of funds in the regions of Ukraine has not been executed.

It should be noted that the greatest impact was made by the measures that were financed from the State 
Fund for Environmental Protection (39 were executed from the planned 51), indicating a more efficient use of resources by the State Fund of Environment Protection compared with the state budget and other sources (Official site of the Ministry of Ecology and Natural Resources of Ukraine).
However, this state of realization of measures aimed at improving ecological and economic interactions and mechanisms for implementing green economy indicates the existing potential for their realization. Even those measures that were fulfilled only by one third provide a positive dynamics of green growth in Ukraine in 2010-2015, as shown in Table 2.

Table 2. Indicators of "green growth" of Ukraine in 2010-2015

\begin{tabular}{|c|c|c|c|c|}
\hline Indicator & Value in 2010 & Value in 2015 & Change & Change, $\%$ \\
\hline $\begin{array}{l}\text { The amount of carbon dioxide emissions in the energy sector, thousand } \\
\text { tons }\end{array}$ & 130328.4 & 106956.5 & -23371.9 & -17.9 \\
\hline Carbon productivity of GDP UAH/tons $\mathrm{CO} 2$ & 5444.9 & 5928.2 & 483.3 & 8.9 \\
\hline $\begin{array}{l}\text { GDP in constant prices of } 2010 \text { per units of consumed energy, } \\
\text { UAH/tons of oil equivalent }\end{array}$ & 14585.0 & 17344.6 & 2759.6 & 18.9 \\
\hline Volume of generated waste, thousand tons & 425914.2 & 312267.6 & -113646.6 & -26.7 \\
\hline GDP in constant prices of 2010 per units of generated waste, $\mathrm{UAH} / \mathrm{kg}$ & 2534.2 & 3076.8 & 542.6 & 21.4 \\
\hline The amount of water intake, million cubic meters & 14846.0 & 9699.0 & -5147.0 & -34.7 \\
\hline $\begin{array}{l}\text { GDP in constant prices of } 2010 \text { per units of water consumption, } \\
\text { UAH/cubic meter }\end{array}$ & 109.9 & $134 . .8$ & 24.9 & 22.7 \\
\hline Emissions of pollutants, thousand tons & 6678.0 & 4521.3 & -2156.7 & -32.3 \\
\hline $\begin{array}{l}\text { Volume of capital investments into environmental protection, million } \\
\text { UAH (at current prices) }\end{array}$ & 2761.5 & 7675.6 & 4914.1 & 178.0 \\
\hline
\end{tabular}

The analysis of these data shows that the values of all indicators of production efficiency are growing (carbon productivity, volume of GDP per units of consumed water, energy consumption and waste creation). However, the indicators of consumption of resources (emission of pollutants, water intake, generated waste, the amount of carbon dioxide emissions in the energy sector) are reduced in dynamics. This trend leads to the conclusion regarding Ukraine's gradual shift from extensive to intensive use of resources with a lower degree of pollution and the urgent need to ensure these positive changes (Official website of the State Statistics of Ukraine).

The main reasons for the low efficiency of state stimulation of ecological and economic interactions in Ukraine include: imbalances in the regulatory and budget provision of measures to stimulate environmental and economic interactions; formal approach to the planning of the necessary measures and their implementation; difficulties in getting incentives guaranteed by the state for maintaining environmentally-oriented activities; insufficient control over the compliance with environmental legislation and the presence of corrupt components; insufficient level of information provision for the "green economy" and sustainable development.

Ukraine should also consider the concept of the system of environmental management and sustainable development proposed by The International Organization for Standardization (ISO). The use of these standards can ensure the confidence of all stakeholders that environmental impact can be measured and improved. Therefore, an organization can reduce the costs on waste management and save on the consumption of energy and materials (A.M. Smit and E. Kotzee, 2016).

To improve the effectiveness of implementation of environmental and economic projects, it is necessary to strengthen the control and responsibility for the execution of the planned activities on all levels, to ensure continuous examination of the current legislation regarding its compliance with the principles of sustainable development and to create a modern legal framework for the implementation of innovative environmental and economic policies; to use public examination and independent audit; to ensure continuous dialogue between representatives of business and society.

One way to improve the regulatory provision of sustainable development should be the approval of the National Action Plan on Environmental Protection for the period 2016-2020, which pays considerable attention to the stimulation of optimal environmental and economic interactions. Of the five declared strategic objectives three are directly or indirectly connected to environmental and economic interactions, namely: formation of environmental values and principles of sustainable consumption and production in the society; sustainable development and the use of natural resources of Ukraine; integration of environmental policy into the process of social and economic development of Ukraine (official site of the Ministry 
of Ecology and Natural Resources of Ukraine, "Draft of the National Action Plan for Environmental Protection for 2016-2020" as of October 13, 2015).

A delay in the introduction of this document casts doubts on the reality of achieving these goals considering the uncertainty regarding the sources and the scope of funding of the planned activities.

Significant improvement is required with the coverage of benefits of environmental and profitable business, stimulation of transition to the standards of the "green economy", as well as rational environmental and economic interactions. It is also important to disseminate communication initiatives regarding the available technologies of the green industry and opportunities for their implementation. An example of such initiatives can be considered the Institute of Green Economics (http://greeneconomics.org.ua/uk/), founded in 2013 by the leading experts in the field of academic science, business and public administration to promote the green economy in Ukraine through association of Ukraine's leading experts in the field of green economy to develop its methodological and practical principles, promotion of the green economy by the media, state government, public and business, attracting investments and innovative technologies to develop green businesses.

A restraining factor in the development of green technologies is the difficulty of calculating the economic impact of their implementation resulting in the lack of adequate motivation for economic entities and state authorities to use such technologies. The most appropriate way to solve this problem is the use of economic and mathematical approaches to stimulate environmental and economic interactions in the projection of business environment based on the principles of sustainable development.

The modeling of ecological and economic interactions is based on comparison of the expected economic results with the costs of achieving them. Typical for the environmental and economic modeling is a simultaneous combination of both purely economic restrictions, the main purpose of which is the amount of profits exceeding the costs, and environmental restrictions (the need for compliance with environmental regulations, reduction of pollutant emissions, etc.).

In the light of this, to justify the values of environmental expenditures taking into account the socio-economic impact and their geographic distribution, it is expedient to use the following balanced ecological and economic models of the "input-output" type, which are based on the balance method - the method of mutual comparison of the available material, labor and financial resources and the needs in them: output optimization model; revenue optimization model; balance model with increased consumption of resources; balance model of equilibrium prices.

In addition to standard economic restrictions, to quantify the reflection of the nature of ecological and economic interactions the above mentioned model should also include environmental restrictions.

An example of determining the effectiveness of environmental and economic interactions with the help of economic modeling is the use of output optimization model with additional environmental restrictions.

Let $\mathrm{F}\left(\mathrm{x}_{1}, \mathrm{x}_{2}, . . \mathrm{x}_{\mathrm{n}}\right)$ be the target function of output that characterizes production, which uses the $n$-th quantity of resources. We will assume that there are $\mathrm{m}$ types of contamination from production, which are presented in the pollution intensity matrix:

$C_{p}=\left(\begin{array}{llll}C_{11} & C_{12} & \ldots & 0.2 \\ C_{21} & C_{22} & \ldots & 0.2 \\ \ldots & \ldots & \ldots & \ldots \\ C_{m 1} & 0.3 & \ldots & 0.1\end{array}\right)$,

where $C_{i j} \geq 0$ - the amount of the i-th pollution produced by using a unit of the $\mathrm{j}$-th resource. Then, the vector of pollution is defined as follows:

$$
\begin{aligned}
\bar{z}^{T} & =C_{p} \bar{x}^{T} \\
z_{k} & =\sum_{j=1}^{n} C_{k j} x_{j}, k=1,2 \ldots, m,
\end{aligned}
$$

where $\bar{x}$ is a row vector of resources. We will introduce matrix A of restriction coefficients on resources and the vector of restrictions $\bar{b}$ defined by the production capacities. It is also necessary to consider the vector of environmental standards $\bar{z}^{*}$ allowable (limit) wastes for each type of pollution. These standards are usually set according to the existing MPC norms (maximum permissible concentration) of contaminants.

Then, to determine the optimal output of production, it is necessary to find the maximum of function:

$\mathrm{F}\left(\mathrm{x}_{1}, \mathrm{x}_{2}, \ldots, \mathrm{x}_{\mathrm{n}}\right)=\mathrm{F}(\bar{x}) \rightarrow \max$

at an admissible set: 
$\left[\begin{array}{l}\bar{x} \geq 0, \bar{z} \geq 0 \\ A \bar{x}^{T} \leq \overline{\mathrm{b}}^{\mathrm{T}} \\ \overline{\mathrm{z}} \leq_{\mathrm{Z}}{ }^{*}\end{array}\right.$.

The given problem statement of production optimization subject to observance of environmental regulations corresponds to sustainable development. Unlike traditional optimization models, the admissible set of which is formed only by the first two production relations (5), this model also includes restrictions regarding the "purity" of production. To meet the last condition (5), which according to (3) in its expanded form, looks like restrictions for each type of pollution:

$$
\sum_{j=1}^{n} C_{k j} x_{j} \leq z_{k}^{*}, k=1,2 \ldots, m \text {. }
$$

It is necessary either to upgrade the used technology, or to use the resources, which result in smaller pollution. Otherwise, due to restriction (6), the allowable amounts of the used resources $x$ may be so insignificant that provision of economically acceptable production volumes is not possible.

The use of the described model is more expedient in the field of macroeconomics under conditions of identification of output with the country's GDP or with the gross product of the region. Then, the condition (6) should be used to manage the technological policy (possibly, on the legislative level). For microeconomics on the level of an individual production, this model will not work, because the producer is interested above all in achieving the biggest output (4), and the issue of compliance with environmental standards (6) is secondary for him.

To take into account the environmental factor on the microeconomic level, it is necessary to use the model of revenue optimization to consider the value terms of the target function and payments for exceeding pollution standards.

Let $p$ be an aggregate price of output and vector components

$$
\bar{w}=\left(w_{1}, w_{2}, \ldots, \mathrm{w}_{m}\right)
$$

representing the costs of elimination of pollutants if they exceed the relevant standards (during the violation of the third condition in (5)). Then, the function of revenue from production will look like:

$$
P=p F(\bar{x})-\bar{w} \bar{\delta},
$$

where $\bar{\delta}$ - the vector of "inclusion" of financial sanctions to eliminate pollution, $\delta=\left\{\begin{array}{l}0, z_{j} \leq \mathrm{z}_{\mathrm{j}}^{*}, \\ 1, z_{j}>\mathrm{z}_{\mathrm{j}}^{*}\end{array}, j=1,2, . . m\right.$,

$\bar{z}-$ the vector of pollution, defined by formulae

and (3), and $z_{j}^{*}$ - components of the vector of the maximum allowable pollution:

$\bar{z}^{*}=\left(z_{1}^{*}, z_{2}^{*}, \ldots, z_{m}^{*}\right)$.

To simplify the model, we assume that the usual environmental costs are included in the fees for nature management, therefore, the second term of the profit function with minus sign expresses the payment for excessive burden on the environment. In this case, (8) can be considered as a production function, the arguments of which are resources $\bar{x}$, pollution $\bar{z}$, maximum permissible concentration norms $\bar{z}^{*}$ and fines for violation of environmental regulations $\bar{w}$.

The model of revenue optimization from the output of production with the use of resources vector $\bar{x}$ and with technology, which is characterized by the production function $\mathrm{F}$, can be defined as follows: to find a maximum of function (8) at an admissible set of solution.

$$
\left\{\begin{array}{l}
\bar{x} \geq \overline{0} \\
A \bar{x}^{T} \bar{b}^{T}
\end{array}\right.
$$

at a set restriction (10) on the vector $\bar{z}$.

This model contains both production capacities (given matrix $\mathrm{A}$ of restriction coefficients and vector $\bar{b}$ of restrictions on resources) and the standards of technological impact on the environment as well as the costs to eliminate the consequences of their excess (vectors $\bar{w}$ and $\bar{z}$ ).

The use of this model makes it possible to demonstrate that with "harsh" environmental legislation producers are forced to use more advanced technologies in order to reduce specific technogenic wastes - coefficients of matrix $\mathrm{Cp}$ in (1). Therefore, the model can be used for the purposes of microeconomics on the level of enterprises, production complexes and sectoral output.

To model the environmental and economic systems on the macro and micro levels, it is also possible to use balance models of diversified economy, one of which is a balance model with an increased consumption of resources. 
As a rule, the matrix of inter-sectoral balance has a significant supply of productivity. In some cases, to minimize technogenic wastes, it is necessary to spend more resources per unit of output increasing their intra-sectoral consumption (for example, construction of sewage treatment plants, implementation of waste treatment technologies, etc.). This increases the coefficients of the matrix of direct costs $\mathrm{A}$, which, in turn, leads to the reduction in the supply of productivity.

Let A be the matrix of inter-sectoral balance, $\bar{x}$ the vector of the sector's gross output, $\bar{y}$ - the vector of final consumption. Then, the equation of inter-sectoral balance will look like:

$$
\bar{x}=A \bar{x}+\bar{y} \text {. }
$$

Let us assume that for the measures of ecological and environmental protection, it is necessary to increase intra-sectoral consumption. In this case, a new matrix of direct costs will consist of the sum of the initial matrix A and some additions. Accordingly, the vectors of gross output and final consumption will also change.

$$
\begin{aligned}
& \bar{A}=A+\Delta A, \\
& \bar{x}^{*}=\bar{x}+\Delta \bar{x}, \\
& \bar{y}^{*}=\bar{y}+\Delta \bar{y} .
\end{aligned}
$$

The new matrix $\bar{A}$ of intra-sectoral equation (12) will take the form:

$$
\bar{x}+\Delta \bar{x}=(A+\Delta A)(\bar{x}+\Delta \bar{x})+\bar{y}+\Delta \bar{y}
$$

In view of equality (12), we obtain an equation to change the vector of gross output:

$$
(E-\bar{A}) \Delta \bar{x}=\Delta A \bar{x}+\Delta \bar{y} .
$$

We will consider a special case of the change in matrix $\mathrm{A}$, when all its elements increase by $1+\alpha$ times, while $\alpha$ satisfies the conditions of the supply of productivity A (matrix $(1+\alpha) A$ is also productive, $\Delta A=\alpha A$ ), then, the equation (17) in view of equality (12) will take the form

$$
(\mathrm{E}-(1+\alpha) A) \Delta \bar{x}=\alpha(\bar{x}-\bar{y})+\Delta \bar{y} \text {. }
$$

This equation connects the change in gross output with changes in the consumption of resources and the vector of final consumption. We will have the following expression $\Delta \bar{x}$ :

$$
\Delta \bar{x}=(\mathrm{E}-(1+\alpha) A)^{-1}(\alpha(\bar{x}-\bar{y})+\Delta \bar{y}) .
$$

We will analyze expression (19). Because of the second criterion of productivity of matrix $(1+\alpha) A$ the matrix is positive $(\mathrm{E}-(1+\alpha) A)^{-1}$, then, even in the case of zero growth in the vector of final consumption the gross output increases as $\bar{x}-\bar{y}>\overline{0}$.

An important objective for an enterprise is to determine the required size of change in the prices of output caused by the necessity to compensate environmental damage (fines, environmental taxes, etc.). For this purpose, it is possible to use a balance model of equilibrium prices.

In building this model, we will assume that gross output and intra-sectoral consumption remain unchanged, that is, the matrix of direct costs A remains unchanged.

We will use a cost model of equilibrium prices. In the matrix, it takes the form:

$\bar{p}=A^{T} \bar{p}+\bar{w}$,

Where $\bar{p}$ and $\bar{w}$ are the vector of prices on the sector's output and the vector of added value. The money spent on pollution elimination increases the components of the vector of added value $\bar{w}$. Let the vector $\bar{w}_{e H}>\bar{O}$ be the "environmental burden" in the form of taxes, penalties, costs for engineering and preventive measures. Then, the vector of prices on the sector's output considering environmental costs is defined as follows:

$\bar{p}^{*}=\left(E-A^{T}\right)^{-1}\left(\bar{w}+\bar{w}_{e H}\right)$.

Therefore, taking into account the relationship (21) the change in output prices will be:

$\Delta \bar{p}=\bar{p}^{*}-\bar{p}=\left(E-A^{T}\right)^{-1} \bar{w}_{e H}$.

As the components of the matrix $\left(E-A^{T}\right)^{-1}$ are inherent because of the productivity of the matrix of costs $\mathrm{A}$, then, $\Delta \bar{p}>0$. It should be noted that in this case, the consumption of resources for the output remains unchanged (O. Sharapov, V. Derbentsev, D. Semyonov, 2004).

The use of mathematical modeling of environmental and economic interactions makes it possible to determine prices that will balance finances of all sectors and economic losses, on fighting pollution, on predicting the impact of changes in added value on prices (for example, due to the changing demand for capital investments), to determine the impact of expected changes in prices on the added value in the 
sectors and, therefore, on conditions for the reproduction of a certain conservation strategy.

A wide use of mathematical modeling for the process of projection of business environment on the basis of sustainable development will make it possible to determine quantitative indicators of efficiency of ecological and economic interactions, to optimize the system of environmental regulation and to provide incentives on the national and regional levels.

\section{Conclusion}

In spite of the difficult environmental situation in Ukraine, an important issue on the state level is the implementation of "ecologization" of production and promotion of the standards of "green" economy as the main mechanisms for achieving sustainable environmental and economic development.

In Ukraine, in solving environmental problems, preference is given to the regulation of emissions and implementation of administrative and economic norms of coercion. In the presence of a broad range of instruments for motivating "ecologization" of business entities, economic and market incentives are practically not used.

The declared course of Ukraine towards the achievement of sustainable development is carried out formally; the adopted strategic documents do not associate the process of achievement of sustainable development with the need to solve environmental problems.

The measures that are aimed at developing the optimal environmental and economic interactions in the implementation of the Strategy of the National Environmental Policy of Ukraine till 2020 (in the period from 2011 to 2015) and the National Action Plan for Environmental Protection for 2011-2015 have been realized only by one third, which has led to their low effectiveness.

There is a need to introduce a new national framework document that would outline strategic directions for the long-term development of Ukraine and facilitate the integration of sustainable development goals into the national plans, strategies and programs. Corresponding to these requirements is the draft of Sustainable Development Strategy of
Ukraine till 2030 developed with the support of the United Nations Development Program in Ukraine.

To improve the effectiveness of implementation of environmental and economic projects, it is necessary to strengthen the control and responsibility for the execution of the planned activities on all levels, to ensure continuous examination of the current legislation regarding its compliance with the principles of sustainable development and to create a modern legal framework for the implementation of innovative environmental and economic policies; to use public examination and independent audit; to ensure continuous dialogue between representatives of business and society.

A restraining factor in the development of green technologies is the difficulty of calculating the economic impact of their implementation resulting in the lack of adequate motivation for economic entities and state authorities to use such technologies. The most appropriate way to solve this problem is the use of economic and mathematical approaches to stimulate environmental and economic interactions in the projection of business environment based on the principles of sustainable development.

To achieve these objectives, it is necessary to use such balance models as output optimization model; revenue optimization model; balance model with increased consumption of resources; balance model of equilibrium prices, which, in addition to standard economic restrictions, to quantify the reflection of the nature of ecological and economic interactions, should also include environmental restrictions.

Further research in this area should be directed at the analysis of possibilities to use various mathematical and economic models to formalize the stimulation of ecological and economic interactions and the promotion of green technologies, ways to improve the mechanisms of state stimulation of "ecologization", specification of quantitative and qualitative parameters necessary for the implementation of "sustainable economy" in Ukraine, substantiation of ways to improve the existing regulatory framework.

\section{References}

1. "Derzhavna polityka staloho rozvytku na zasadakh "zelenoi ekonomiky". Analitychna zapyska. Natsionalnyi instytut stratehichnykh doslidzhen. Retrieved from http://www.niss.gov.ua/articles/1237/

2. Infohrafika: Struktura ukrainskykh zemel ta spivvidnoshennia kilkosti chornozemiv v Ukraini ta inshykh yevropeiskykh krainakh. Ofitsiinyi sait Derzhheokadastru. Retrieved from http://land.gov.ua/info/infohrafika-struktura-ukrainskykhzemel-ta-spivvidnoshennia-kilkosti-chornozemiv-v-ukraini-ta-inshykh-ievropeiskykh-krainakh/

3. Instytut zelenoi ekonomiky. Retrieved from http://green-economics.org.ua/uk/pro-nas/ 
4. Navkolyschne seredovysche. Ofitsinyi sait Derzhstatu Ukrainy. Retrieved from http://www.ukrstat.gov.ua/druk/publicat/kat_u/publnav_ser_u.htm

5. Otsinka vykonannia stratehii derzhavkoi ekolohichnoi polityky Ukrainy na period do 2020 roku ta natsionalnoho planu dii z okhorony navkolyshnoho pryrodnoho seredovyscha na 2011-2015 roky. Ofitsiinyi sait Ministerstva ekolohii ta pryrodnykh resursiv Ukrainy. Retrieved from http://www.menr.gov.ua/press-center/news/150-news28/3362-otsinkavykonannia-stratehii- derzhavnoi-ekolohichnoi-polityky-ukrainy-na-period-do-2020-roku-ta-natsionalnoho-planu-dii-zokhorony-navkolyshnoho-pryrodnoho-seredovyshcha-na-2011-2015-roky

6. Podatkovyi kodeks Ukrainy. Retrieved from http://zakon3.rada.gov.ua/laws/show/2755-17

7. Pro okhoronu navkolyshnoho pryrodnoho seredovyscha: Zakon Ukrainy v redaktsii vid 25 chervnia 1991 roku nomer 41. Holos Ukrainy vid 24.07.1991.

8. Pro Osnovni zasady (stratehiiu) derzhavnoi ekolohichnoi polityky Ukrainy na period do 2020 roku: Zakon Ukrainy vid 21 hrudnia 2010 roku nomer 2818-VI. Ofitsiinyi visnyk Ukrainy vid 24.01.201 1nomer 3, 13, stattia 158.

9. Pro prohramu okhorony navkolyshnoho pryrodnoho seredovyscha Sumskoi oblasti na 2016-2018 roky. Retrieved from http://sm.gov.ua/images/docs/programa/programma_eco.pdf

10. Pro Stratehiiu staloho rozvytku "Ukraina - 2020". Ukaz Prezydenta Ukrainy vid 12 sichnia 2015 roku nomer 5/2015. Ofitsiinyi visnyk Ukrainy vid 23.01.2015 nomer 4, 8, stattia 67.

11. Pro vnesennia zmin do Budzhetnoho kodeksu Ukrainy schodo tsilovoho spriamuvannia ekolohichnoho podatku: Zakon Ukrainy vid 24 hrudnia 2015 roku nomer 918-VIII. Ofitsiinyi visnyk Ukrainy vid 12.01.2016 nomer 2, 199, stattia 56.

12. Pro zatverdzhennia normatyviv hranychno dopustymykh vykydiv zabrudnuiuchykh rechovyn iz statsionarnykh dzherel: Nakaz Ministerstva navkolyshnioho pryrodnoho seredovyscha Ukrainy vid 27 chervnia 2006 roku No. 309. Ofitsiinyi visnyk Ukrainy vid 16.08.2016 nomer 31, 236, stattia 2259.

13. Pro Zatverdzhennia Prohramy okhorony navkolyshnoho pryrodnoho seredovyscha mista Fastova na 2016-2020 roky. Retrieved from http://fastiv-rada.gov.ua/node/6521

14. Proekt natsionalnoho planu dii z okhorony navkolyshnoho pryrodnoho seredovyscha na 2016-2020 roky. Ofitsiinyi sait Ministerstva ekolohii ta pryrodnykh resursiv Ukrainy. Retrieved from http://www.menr.gov.ua/public/discussion/4259-1

15. Report of the United Nations conference on environment and development, 3-14 June 1992. Retrieved from http://www.un.org/documents/ga/conf151/aconf15126-1annex1.htm

16. Sharapov, O. D. Derbentsev, V. D., Semyonov, D. E. (2004). Systemnyi analiz: Navch. posibnyk. Kyiv: KNEU, 231 p.

17. Smit, A. M., and Kotzee, E. (2016). Investigating environmental management accounting in the chemical industry in South Africa. Investment Management and Financial Innovations, 13(1-1). Retrieved from http://dx.doi.org/10.21511/imfi.13(1-1).2016.02

18. Stratehiia staloho rozvytku Ukrainy na period do 2030 roku. Retrieved from http://www.ua.undp.org/content/dam/ukraine/docs/EE/Rio/Sust-Dev-Strat_Version-3-6.pdf?download

19. Sutarmin, Darmawan, A., Azizah, S. N., and Jatmiko, D. P. (2017). An empirical evidence: supplier behavior in the natural materials of buyer - supplier relationship. Problems and Perspectives in Management, 15(1-1), 158-165. Retrieved from http://dx.doi.org/10.21511/ppm.15(1-1).2017.02

20. The United Nations Environment Programme. Green Economy. Retrieved from http://web.unep.org/greeneconomy/

21. Vydano pershyi derzhavnyi eko-kredyt. Ofitsinyi portal orhaniv vykonavchoi vlady Ukrainy. Retrieved from http://www.kmu.gov.ua/control/uk/publish/article?art_id=249667787\&cat_id=244276429 